\title{
Borsa İstanbul (BIST) 100 Endeksi ile Zımni Volatilite (VIX) Endeksi Arasındaki Eş-Bütünleşme ve Granger Nedensellik
}

\section{Emine KAYA}

Ağrı İbrahim Çeçen Üniversitesi, İktisadi ve İdari Bilimler Fakültesi, İşletme Bölümü , Ağrı

\section{Özet}

Finansal serbestleşmeye bağlı olarak, finansal piyasalar birlikte hareket etmeye başlamıştır. Finansal piyasaların entegre olmasından yola çıkılarak yapılan bu çalışmanın amacı, BIST 100 endeksi ile VIX endeksi arasındaki nedensellik ilişkisini tespit etmektir. 02/01/2009-11/01/2013 dönemini kapsayan çalışmada, BIST 100 endeksi ve VIX endeksine ilişkin zaman serileri kullanılmıştır. Araştırmada, Johansen-Jeselius eş-bütünleşme testi ve vektör hata düzeltme modeli uygulanmıştır. Johansen-Juselius eş-bütünleşme testi sonuçları BIST 100 endeksi ile VIX endeksi arasında eş-bütünleşme olduğunu göstermiştir; hata düzeltme modeli ise BIST 100 endeksinin VIX endeksinden etkilendiğine işaret etmektedir.

Anahtar Kelimeler: Finansal Entegrasyon, Zımni Volatilite, VIX Endeksi.

\section{Cointegration and Granger Causality Between Implied Volatility (VIX) Index and Istanbul Stock Exchange (BIST) 100 Index}

\begin{abstract}
Depending on the financial liberalization, financial markets have begun to move together. The aim of this study made on the basis of integration of financial markets is to determine the causality relationship between BIST 100 index and VIX index. In the study covering $02 / 01 / 2009-11 / 01 / 2013$ period, time series related to BIST 100 index and VIX index are used. In the research, Johansen-Juselius cointegration test and vector error correction model are applied. Johansen-Juselius cointegration test results show that there is cointegration between BIST 100 index and VIX index; however error correction model indicates BIST 100 index are affected by VIX index.
\end{abstract}

Key Words: Financial Integration, Implied Volatility, VIX Index.

\section{Giriș ${ }^{1}$}

Küreselleşmenin bir sonucu olarak ekonomik sınırların ortadan kalkması ile ülke ekonomileri yakınlaşmaya başlamıştır. Piyasalar, uluslararası boyutta değişime maruz kalmıştır. Bu değişimin avantajları olduğu gibi dezavantajları da söz konusu olabilmektedir.

1990’l1 yıllarda 1994 Meksika krizi, 1997 Asya krizi, 1999-2002 Latin Amerika krizleri gibi finansal krizler ortaya çıkmış, bu dönemlerde ABD, Avrupa ülkeleri ve Japonya finansal piyasalarında beklenmedik hisse senedi fiyat dalgalanmaları görülmüştür. Bu dalgalanmaların ve krizlerin ülke riskinin yayılma etkisinden kaynaklanabileceği araştırmacılar tarafından ifade edilmiştir (Hassan ve diğerleri, 2003: 64). Bu şekilde, bir ülkede oluşup diğer ülkeleri de etkileyen krizler finansal piyasaların bütünleşik olması görüşünü desteklemektedir. Finansal piyasa entegrasyonu 1990'lı yıllarda artmış ve bu durum yatırımcıların dikkatlerini uluslararası piyasalara çekmelerine sebep olmuştur (Ayuso ve Blanco, 2000: 265).

\footnotetext{
${ }^{1}$ Bu çalışma Uluslararası İstanbul Finans Kongresi'nde bildiri olarak sunulmuştur. Yapılan eleştiriler doğrultusunda varyans ayrıştırma tablosu kaldırılarak, hata düzeltme modeline yer verilmiştir.
}

Bir ülkenin hisse senedi piyasasındaki volatilitenin bir diğer ülkenin hisse senedi piyasasındaki volatiliteyi etkilemesi, volatilitenin yayılma etkisi olarak adlandırılmaktadır. Hisse senedi piyasası volatilitesi, gelişen piyasalarda gelişmiş piyasalar göre daha fazladır. Gelişen piyasalarda volatilitenin yüksek olması ekonomik faktörlerden kaynaklanan riskle ilişkisiz olup; daha çok finansal istikrarsızlıkla bağlantılıdır (Wang, 2007: 798).

Gözlenen opsiyon fiyatlarına bağlı olarak opsiyon fiyatları ile oluşturulan zımni volatilite, gelecekteki volatiliteyi öngörmede yol gösterici özellik taşımaktadır. Zımni volatilite, piyasa riskini ölçmeyi sağlamakta ve varlık fiyatlama modellerinde kullanılmaktadır. Dolayısıyla zımni volatilitedeki değişim tahmin edilerek, beklenen getirilerdeki değişim de öngörülebilmektedir (Konstantinidi ve diğerleri, 2008: 2401). Zımni volatilite gelecekteki volatiliteye ilişkin bilgiler içermekte, gelecekteki volatiliteyi tahmin etmede başarılı sonuçlar vermektedir. Bununla birlikte VIX endeksinin beklenen getirileri ve S\&P 500 volatilitesini öngörmede başarılı olduğu literatürde yer almaktadır (Fleming, 2008: 341; Becker ve diğerleri, 2009: 1033; Blair ve diğerleri, 2001: 6). 
VIX endeksi, Chicago Opsiyon Borsası (Chicago Board of Options Exchange) tarafindan vadesine 22 işlem günü (30 takvim günü) kalmış olan S\&P 100 endeksi üzerine yazılmış Amerikan tipi alım ve satım opsiyonlarından hesaplanmış ve örtülü volatiliteyi belirlemek amacıyla oluşturulmuş endekstir. VIX endeksinde her bir opsiyonun fiyatının yakın zamanda işlem görmüş opsiyonların ortalaması alınarak hesaplanması ile alım/satım fiyat dalgalanmalarından kaynaklanan sorunlar elimine edilebilmektedir.

VIX endeksi 2003 yılına kadar beklenen kâr paylarının zamanını ve de miktarını dikkate alan binominal değerleme yöntemi doğrultusunda hesaplanmıştır (Blair ve diğerleri, 2001: 9). Öte yandan VIX endeksi 2003 yılından sonra S\&P 500 endeks opsiyonlarına göre oluşturulmaktadır. Bu tarihten sonra endeks hesaplaması uzun vadeli Black-Sholes modeli dikkate alınarak, likiditesi yüksek S\&P 500 opsiyonları için yapılmaktadır.

VIX endeksi yıllık zımni volatilite endeksi olduğundan günlük zımni volatilite endeksinin oluşturulması gerekmektedir ve $V I X \sqrt{252}$ formülü kullanılarak günlük zımni volatilite endeksi hesaplanmıştır (Bali ve Weinbaum, 2007: 10). Şekil 1'de S\&P 500 endeksinin 02/01/2009 ile $11 / 01 / 2013$ tarihleri arasındaki günlük seyri yer almaktadır.

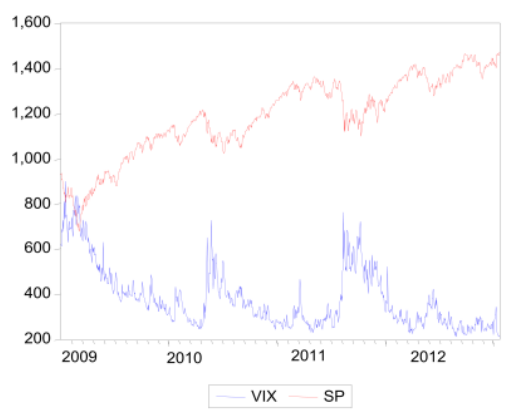

Şekil 1: S\&P 500 ve VIX Endeksleri Günlük Seyri

Şekil 1 S\&P 500 ve VIX endeksinin 02/01/2009 ile $11 / 01 / 2013$ tarihleri arasındaki seyrini göstermektedir. S\&P 500 endeksi, 2009 y1lının ilk dönemlerinde düşüş trendine girmiştir. $\mathrm{Bu}$ durum 2008 y1lı krizinin etkilerini göstermektedir. Daha sonraki dönemlerde 2013 yılına doğru S\&P 500 endeksinin yükseliş trendine girdiği ve yükselişe devam ettiği görülmektedir. VIX endeksinin günlük seyrine bakıldığında, S\&P 500 endeksinin aksine bir seyir izlediği görülmektedir. VIX endeksi 2009 yılının ilk dönemlerinde yükseliş, 2009 yılından sonra 2013 yılına doğru düşüş trendine girmiştir. Ara dönemlerde yükselişler olmasına rağmen, bu durum endeksin genel düşüş trendine girmesini değiştirmemiştir.

Literatürde VIX endeksi üzerine yapılan çalışmalar genelde VIX endeksinin S\&P 500 endeksi ile olan ilişkisini belirleme ya da zımni volatiliteyi öngörme üzerinedir. VIX endeksinin diğer piyasalar ile ilişkisini tespit etmeye yönelik çok az sayıda çalışma bulunmaktadır. VIX endeksinin zımni volatilite endeksini öngörmede başarılı olması, bu endeksin S\&P 500 endeks opsiyonlarına göre oluşturulması ve de S\&P 500 endeksinin dünya piyasaları ile olan ilişkisinin sonucu olarak VIX endeksinin diğer piyasalar ile etkileşim içinde olabileceği beklenilebilir. VIX endeksinin diğer piyasaları etkileyebileceği durumundan yola çıkılarak yürütülen bu çalışmada, VIX endeksinin BIST 100 endeksini etkileyip etkilemediği araştırılacaktır.

\section{Literatür İncelemesi}

Finansal serbestleşme ile entegrasyonun artması, hisse senedi piyasalarının birbirini etkilemesi sonucunu doğurmuştur. 1980'li yıllardan bu yana finansal liberalleşme iktisat ve finans literatüründe akademisyenlerin dikkatini çekmiş ve bu alanda çalışmalar yoğunluk kazanmıştır. Bu bölümde finansal piyasalar arasındaki etkileşim üzerine yapılan çalışmalar özetlenecektir.

Naranjo ve Protopapadakis (1997), NYSE, AMEX, NASDAQ endeksleri üzerine çalışmışlardır. Yazarlar araştırmalarında CAPM modelini kullanarak, endeksler arasındaki ilişkiyi incelemişlerdir. Elde ettikleri sonuçlar, NASDAQ endeksinin NYSE ve AMEX ile entegrasyonun düşük olduğu yönündedir. Bir başka çalışma Claessens ve Schmukler (2007) tarafından yürütülmüştür. Çalışmaya 111 ülkeden 39517 firma dâhil edilerek doğrusal panel ve tobit modeller uygulanmıştır. Elde edilen sonuç, birçok ülkenin entegrasyona aktif olarak katıldığı; ancak en aktif entegrasyonun büyük firmaların yer aldığı gelişmiş ülkelerde olduğudur. Amira ve diğerleri (2011), ABD, Kanada, İngiltere, Fransa sermaye piyasaları üzerine araştırma yapmışlardır. Çalışmada EGARCH ve GARCH modelleri kullanılmıştır. Yazarlar, getiri etkisinin dikkate alınmaması durumunda, hisse senedi piyasaları etkileşiminde volatilitenin önemli etkisinin olduğunu savunmuşlardır. Zhou ve diğerleri (2012), Çin, Asya, Avrupa ve Kuzey Amerika’ya ait 11 hisse senedi piyasası endeksi arasındaki yayılma etkisini Vektör otoregresyon (VAR) modeli ile araştırmışlardır. Mortgage krizi döneminde ABD hisse senedi piyasalarının baskın bir şekilde diğer piyasaları etkilediği ve 2005 yılından sonra da Çin hisse senedi piyasalarının diğer piyasalar üzerinde pozitif etkiye sahip olmaya başladığ 1 yazarlarca savunulmuştur. Hisse senedi piyasaları ilişkileri için Su (2011), çalışmasını ABD, İngiltere, Japonya, Hong Kong piyasalarını kapsayacak şekilde yürütmüştür. Yazarın VAR modelini kullanarak elde ettiği sonuçlar, bu dört hisse senedi piyasası arasında dinamik ilişki olduğu ve ABD ile Japonya hisse senedi piyasalarının baskın olarak uygulama kapsamındaki diğer ülkelerin hisse senedi piyasalarını etkileyen piyasa olduğudur. Özdemir ve diğerleri (2009) ise ABD hisse senedi piyasaları ile gelişen piyasalar arasındaki Granger nedenselliği araştırmışlardır. Yazarlar, S\&P 500 endeksinden gelişen hisse senedi piyasalarına doğru nedensellik olduğunu savunmuşlardır. Gelişen piyasalar ise Arjantin, Brezilya, Şili, Çin, Endonezya, Malezya, Meksika, Peru, Filipinler, Singapur, Güney Kore, Tayvan, Tayland, Türkiye ve Venezuela ülkelerini kapsamaktadır. Uluslararası hisse senedi piyasalarının uzun ve kısa dönemli dinamik ilişkilerini araştırmaya yönelik bir başka incelemeyi Hassan ve diğerleri (1996), gerçekleştirmişlerdir. Bu amaçla ABD, İngiltere, Almanya, Japonya hisse senedi piyasaları için analizler Vektör Hata Düzeltme (VEC) modeline dayalı eş-bütünleşme modeli ile yapılmıştır. Yazarlar ABD hisse senedi piyasalarının diğer piyasalara yön verdiğini, uzun dönemde ABD ile Japonya ve Almanya hisse senedi piyasalarının eş-bütünleşik olmadığ 1 ve son olarak Japonya, Almanya, İngiltere hisse senedi piyasalarının da eş-bütünleşik olmadığı sonuçlarına ulaşmışlardır. Japonya ve Singapur hisse senedi piyasaları arasındaki ilişkiyi ise Toyoshima ve Hamori (2013), incelemiştir. Bulgular bu hisse senedi piyasalarının entegre olduğunu ve aralarında dinamik çift yönlü ilişkilerinin varlığını göstermiştir. 
Korkmaz ve Çevik (2009), GJR-GARCH modeli ile VIX endeksinin 15 gelișen ülke hisse senedi piyasası üzerinde etkili olup olmadığını araştırmışlardır. Sonuçlar, VIX endeksinin gelişmekte olan ülkelerin koşullu varyansında kaldıraç etkisinin olduğu, piyasaya gelen kötü haberlerin volatiliteyi artırdığ yönündedir ve VIX endeksinin Arjantin, Türkiye, Brezilya, Meksika, Peru, Macaristan, Polonya, Malezya, Tayland, Endonezya hisse senedi piyasalarının volatilitesini artırdığı belirlenmiştir. Hisse senedi piyasası etkileşimi için Vuran (2012), çalışmasında gelişmiş ve gelişmekte olan ülkelerin hisse senedi piyasaları arasındaki uzun dönemli ilişkiyi araştırmıştır. Çalışmada Türkiye, İngiltere ve Almanya hisse senedi piyasaları arasında uzun dönemli ilişkinin olduğu; Brezilya, Arjantin ve Meksika piyasalarının da eş-bütünleşik olduğu; Fransa, Japonya ve ABD'nin de kendi aralarında uzun dönemli ilişkiye sahip olduğu belirlenmiştir.

Horvath ve Petrovski (2013), BEKK-GARCH modeli ile Merkez Batı Avrupa (Bulgaristan, Polonya, Çek Cumhuriyeti); Merkez Doğu Avrupa (Makedonya, Sırbistan, Hırvatistan) ülkeleri üzerine çalışmışlardır. Merkez Doğu Avrupa ile Merkez Batı Avrupa hisse senedi piyasaları arasındaki ilişki düşük olmakla birlikte; Hırvatistan'nın diğer Batı Avrupa ülkelerine göre daha fazla diğer piyasalarla ilişkili olduğunu tespit etmişlerdir. Hisse senedi piyasası entegrasyonunun G7 ülkeleri için araştırmasını Menezes ve diğerleri (2012), VEC modelini ve Granger nedensellik uygulamasını kullanarak çalışmışlardır. Elde edilen bulgulara göre, G7 ülkelerinin entegre olduğu tespit edilmiştir. Mukherjee ve Mishra (2010), Asya ülkeleri ile Hindistan arasındaki volatilite yayılma etkisi incelemiş ve Asya ülkeleri ile Hindistan arasında karşılıklı etkileşim olduğunu belirlemişlerdir.

\section{Yöntem}

$\mathrm{Bu}$ çalışmanın amacı VIX endeksinin BIST 100 endeksi üzerindeki etkisini belirlemektir. Araştırmada 02/01/2009 ile 11/01/2013 tarihleri arasındaki günlük veriler kullanılmıştır. Analizlerde kullanılan BIST 100 endeksine ait zaman serileri www.borsaistanbul.com adresinden, zımni volatilite endeksi olan VIX endeksine ilişkin zaman serileri ise www.finance.yahoo.com internet adresinden temin edilmiştir. BIST 100 endeks serisi, fiyat serisinden getiri serisine $\left(p_{t} / p_{t-1}\right) \times 100$ formülünden yararlanılarak çevrilmiştir. Değişkenlere ilişkin kullanılan harf sembollerinde BIST 100, BIST 100 endeksi bileşik getiri oranlarını, VIX ise zımni volatilite endeksini ifade etmektedir.

$\mathrm{Bu}$ çalışmada zımni volatilite endeksi olan VIX endeksi ve BIST 100 endeksi arasındaki nedensellik araştırılmaktadır. Doğru model seçimi yapmak için, çalışmada ilk olarak değişkenlerin durağan olup olmadıkları incelenmiştir. Daha sonra değişkenler arasında uzun dönemli ilişkiyi araştırmak amacıyla eş-bütünleşme testleri yürütülmüştür. Eş-bütünleşme testlerinin ardından, değişkenler için hata düzeltme mekanizması işletilmiştir.

Granger ve Newbold (1974) zaman serisi verilerinde sahte regresyon üzerine yoğunlaşmışlardır. Dolayısıyla zaman serisi üzerinde yapılan çalışmalarda sahte regresyon sorunu ile karşılaşılması durumu söz konusudur. Bu nedenle ilk önce değişkenlerin durağan olup olmadıkları, durağan iseler hangi seviyede durağan oldukları Augmented DickeyFuller (ADF) ve Phillips-Perron (PP) birim kök testleri ile araştırılmıştır. Daha sonra modele dâhil edilen değişkenler arasında uzun dönemli bir ilişskinin varlığını belirleyen eşbütünleşme sınaması uygulanmıştır. Çalışmada bu amaçla Johansen-Juselius eş-bütünleşme testi kullanılmıştır. Uzun dönem ilişkisinin belirlenmesinde (1) ve (2) numaralı koentegrasyon denklemleri tahmin edilerek hata terimlerinin durağanlığı incelenmektedir (Uysal ve diğerleri, 2009: 167).

$$
\begin{aligned}
& \mathrm{Y}_{\mathrm{t}}=\alpha_{0}+\alpha_{1} \mathrm{X}_{\mathrm{t}}+\mathrm{u}_{1 \mathrm{t}} \\
& \mathrm{X}_{\mathrm{t}}=\alpha_{0}+\alpha_{1} \mathrm{Y}_{\mathrm{t}}+\mathrm{u}_{2 \mathrm{t}}
\end{aligned}
$$

Koentegrasyonun varlığ denklemlerden elde edilen hata terimlerinin (ut) durağan olması beklenir. Bunun için aşağıdaki denklemler tahmin edilir.

$$
\begin{aligned}
& \Delta u_{1 t}=\beta_{1} u_{1 t-1}+\sum_{i=1}^{q} \alpha_{i} \Delta u_{1 t-i}+v_{1 t} \\
& \Delta u_{2 t}=\beta_{1} u_{2 t-1}+\sum_{i=1}^{q} \alpha_{i} \Delta u_{2 t-i}+v_{2 t}
\end{aligned}
$$

Burada $\beta 1=0$ ise hata terimlerinin durağan olmadığına ve değişkenler arasında koentegrasyon ilişkisinin olmadığına; tersi durumda ise koentegrasyon ilişkisinin olduğuna karar verilmektedir. Yalnız, elde edilen bu sonuçlar değişkenler arasında kısa dönem ilişkisinin olup olmadığı konusunda bilgi vermemektedir. Değişkenler arasındaki uzun dönemli ilişkinin zamanla dengeye gelip gelmeyeceği konusunda belirsizlik ortaya çıkmaktadır. Bu durumda VEC modeli tahmin edilmektedir.

Genel olarak nedensellik testlerinde bir uzun dönem denge modeli ile birlikte bir kısa dönem hata düzeltme modeli önerilmektedir. $\mathrm{Bu}$ modeller hem değişkenler arasındaki uzun dönemli ilişkileri (denge ilişkilerini), hem de kısa dönem uyumlama davranışını (dengesizliği) bütünleştirme olanăğ vermektedir.

Örnek olarak, hata düzeltme denklemlerinin açıklanmasını ifade etmek için $\mathrm{Y}$ ve $\mathrm{E}$ şeklinde tanımlanan iki değişkenin bulunduğu varsayılsın. Buna göre iki değişkenin durağan ve eş-bütünleşik olması durumunda, nedensellik testleri VEC modeline göre oluşturulabilir. İki değişken için oluşturulacak VEC şu şekildedir:

$$
\begin{aligned}
& Y_{t}=\alpha_{1}+\sum_{i=1}^{m} \beta_{1 i} \Delta E_{t-i}+\sum_{i=1}^{n} \gamma_{1 i} \Delta Y_{t-i}+ \\
& \sum_{i=1}^{r} \delta_{1 i} E C M_{r, t-1}+u_{t}
\end{aligned}
$$

$$
\begin{aligned}
& \Delta E_{t}=\alpha_{2}+\sum_{i=1}^{m} \beta_{2 i} \Delta E_{t-i}+\sum_{i=1}^{n} \gamma_{2 i} \Delta Y_{t-i}+ \\
& \sum_{i=1}^{r} \delta_{2 i} E C M_{r, t-1}+u_{t}
\end{aligned}
$$

VEC modelinde, $\operatorname{ECM}(r, t-1)$ şeklindeki gecikmeli hata terimleri, hiz ayarlama parametreleri olarak ifade edilmektedir. ECM, Y için $\triangle \mathrm{E}$ 'nin gecikmeli terimleri ya da gecikmeli hata terimleri yoluyla nedenselliğin iki kaynağ olduğu anlamına gelmektedir. Bu kaynaklardan biri ya da daha fazlası Y'yi etkilerse, yani parametreler istatistikî olarak sıfirdan farklı ise bu durumda, "Y veri iken, E, Y'nin Granger nedeni değildir" şeklindeki boş hipotez kabul edilmemektedir. Bu hipotez, hata düzeltme terimleri için ttesti, açıklayıcı değişkenlerin gecikmeli değerleri için ise Ftesti kullanılarak test edilmektedir. VEC sisteminin en az birinde hiz ayarlayan parametrenin istatistiki olarak sıfirdan farklı olması gerekmektedir. Eğer denklem sisteminin tamamında hiz ayarlama parametreleri sıfir ise, uzun dönem denge ilişkisi söz konusu olmamakta ve oluşturulan model hata düzeltme özelliği taşımamaktadır (Yapraklı, 2007: 76). 
Uygulama bulguları Eviews 6 paket programından elde edilmiştir

\section{Bulgular}

Çalışmada öncelikle kullanılan zaman serilerinin tanımlayıcı istatistikleri belirlenmiştir. Daha sonra değişkenlerin zaman serisi özellikleri incelenmiştir. $\mathrm{Bu}$ amaçla ADF ve PP birim kök testleri uygulanarak, bu serilerin zaman içinde durağan olup olmadıkları araştırılmıştır. Tablo 1 serilerin tanımlayıcı istatistiklerini, Tablo 2A ve 2B birim kök testi sonuçlarını göstermektedir.

Tablo 1: BIST 100 ve VIX Endekslerine Ait Tanımlayııı İstatistikler

\begin{tabular}{|c|c|c|c|c|c|c|}
\hline Endeksler & Maks. & Min. & $\begin{array}{c}\text { Std. } \\
\text { Sapma }\end{array}$ & Çarpıklık & Basıklık & $\begin{array}{c}\text { Jarque- } \\
\text { Bera } \\
\text { (prob) }\end{array}$ \\
\hline BIST 100 & 1.11 & 0.92 & 0.02 & -0.07 & 5.25 & $\begin{array}{c}214.7141 \\
(0.000)\end{array}$ \\
\hline VIX & 56.65 & 13.36 & 8.38 & 1.25 & 3.95 & $\begin{array}{c}302.1361 \\
(0.000)\end{array}$ \\
\hline
\end{tabular}

Tablo 1 BIST 100 ve VIX endekslerine ait tanımlayıcı istatistikleri vermektedir. Bir zaman serisinin normal bir dağılım göstermesi için, eğiklik değerinin 0 yani herhangi bir yöne doğru eğikliğinin olmaması ve basıklık değerinin 3 olması gerekmektedir. Ayrıca Jarque-Bera istatistiğinin, olasılık değeri olan p'nin de yüksek olması gerekmektedir (Gujarati, 1995:143). Tablo 1 incelendiğinde, çalışmada kullanılan zaman serilerinin normal dağılım göstermediği görülmektedir.

Tablo 2A: ADF Birim Kök Testi Sonuçları

\begin{tabular}{|c|c|c|}
\hline \multirow{2}{*}{ Değişkenin Adı } & \multicolumn{2}{|c|}{ Seviye Değerleri } \\
\cline { 2 - 3 } & Sabitli & Sabitli/Trendli \\
\hline BIST 100 & $-28.53586(0)^{(\mathrm{a})}$ & $-28.54928(0)^{(\mathrm{a})}$ \\
\hline VIX & $-3.082231(1)^{(\mathrm{b})}$ & $-3.798774(1)^{(\mathrm{b})}$ \\
\hline
\end{tabular}

Tablo 2B: PP Birim Kök Testi Sonuçları

\begin{tabular}{|c|c|c|}
\hline \multirow{2}{*}{ Değişkenin Adı } & \multicolumn{2}{|c|}{ Seviye Değerleri } \\
\cline { 2 - 3 } & Sabitli & Sabitli/Trendli \\
\hline BIST 100 & $-28.55683(4)^{(\mathrm{a})}$ & $-28.57119(5)^{(\mathrm{a})}$ \\
\hline VIX & $-3.177675(25)^{(\mathrm{b})}$ & $-4.074151(20)^{(\mathrm{a})}$ \\
\hline
\end{tabular}

*(a) ve (b) ifadeleri sirasiyla $\% 1$ ve $\% 5$ anlamlılık düzeyinde değişkenlerin durağan olduğunu göstermektedir.

* Parantez içindeki rakamlar ADF birim kök testi için Schwartz Bilgi Kriterine göre seçilen gecikme uzunluklarını, PP birim kök testi için Bartlett kerneli kullanan NeweyWest'e göre belirlenmiş bant genişliklerini ifade etmektedir.

Tablo 2A, ADF birim kök testi sonuçlarını göstermektedir. Tablo 2A'da yer alan sonuçlara göre, çalışmada kullanılan BIST 100 ve VIX endeksi değişkenlerinin seviye değerlerinde [I(0)] durağan oldukları, birim kök içermedikleri belirlenmiştir.

Tablo 2B'de PP birim kök testi sonuçları yer almaktadır. Tablo 2B sonuçlarına bakıldığında, BIST 100 ve VIX endeksi değişkenlerinin seviye değerlerinde [I(0)] durağan oldukları, birim kök içermedikleri belirlenmiştir. Bu durumda ADF birim kök testi sonuçları ile PP birim kök testi sonuçları paralellik göstermektedir. Değişkenlerin durağanlıklarının incelenmesinden sonra değişkenler arasında uzun dönemli ilişki olup olmadığını belirlemek için, Johansen-Juselius eşbütünleşme testi yürütülmüştür. Johansen-Juselius eş- bütünleşme testi BIST 100 bileşik endeks getirisi ve VIX endeksi için uygulanmıştır.

Tablo 3: Johansen-Juselius Eș-Bütünleşme Testi Sonuçları

\begin{tabular}{|c|c|c|c|c|c|}
\hline Değişkenler & $\begin{array}{c}\text { SIfır } \\
\text { Hipotezi }\end{array}$ & $\begin{array}{c}\text { Alternatif } \\
\text { Hipotez }\end{array}$ & $\begin{array}{c}\text { Öz } \\
\text { Değerler }\end{array}$ & $\begin{array}{c}\text { İz } \\
\text { İstatistiği }\end{array}$ & $\begin{array}{c}\text { Max Öz } \\
\text { Değer } \\
\text { Istatistiği }\end{array}$ \\
\hline BIST100 (1) & $\mathrm{r}=0$ & $\mathrm{r}=1$ & 0.136 & $150.867^{(\mathrm{a})}$ & $147.285^{(\mathrm{a})}$ \\
VIX (6) & $\mathrm{r} \leq 1$ & $\mathrm{r}=2$ & 0.0036 & 3.582 & 3.582 \\
\hline
\end{tabular}

*(a) ifadesi \%1 düzeyinde anlamlılı̆̆

*Parantez içerisindeki rakamlar uygun gecikme uzunlukları olup, AIC esas alınarak elde edilmişlerdir.

Tablo 3 Johansen-Juselius eş-bütünleşme testi sonuçlarını göstermektedir. İz istatistiği ve maksimum öz değer istatistiklerine göre, çalışmada kullanılan değişkenler arasında eş-bütünleşmenin olmadığı yönündeki H0 hipotezi reddedilmektedir. Bu durumda BIST 100 endeks getirisi ile VIX endeksi arasında eş-bütünleşme olduğu, uzun dönemde birlikte hareket ettikleri belirlenmiştir.

BIST 100 endeksi ve VIX endeksi değişkenlerinin eşbütünleşik olması uzun dönemli bir denge ilişkisinin olduğu anlamına gelmektedir. Fakat kısa dönemde dengesizlik olup olmadığını anlamak için VEC modeli tahmin edilmektedir. Hata düzeltme terimi ile uzun dönem denge düzeyinden sapma olup olmadığı ve dengeden sapmaların ne kadar süre sonra dengeye geleceği tespit edilebilmektedir. Tablo 4'te VEC modeli tahmin sonuçları yer almaktadır.

Tablo 4: VEC Modeli Tahmin Sonuçları

\begin{tabular}{|c|c|c|}
\hline Değişken & Katsayı & t-istatistiği \\
\hline D(BIST100(-1)) & -0.027380 & -0.624991 \\
\hline $\mathrm{D}$ (BIST100(-2)) & -0.003908 & -0.119515 \\
\hline $\mathrm{D}(\mathrm{VIX}(-1))$ & -0.000572 & -1.879446 \\
\hline $\bar{D}(\mathrm{VIX}(-2))$ & -0.00028 & -0.009475 \\
\hline HDT(-1) & -0.871039 & -17.03522 \\
\hline $\mathrm{C}$ & 0.00036 & 0.061053 \\
\hline $\mathrm{R}^{2}$ & 0.448907 & \\
\hline DW & 1.999912 & \\
\hline F İstatistiği & 163.8929 & \\
\hline
\end{tabular}

Tablo 4'den görüldüğü üzere hata teriminin katsayısı yaklaşı -0.87 'dir. Bu katsayı aynı zamanda ayarlama ve uyarlama hızlarının da göstergesi olma niteliği taşımaktadır. Modelde bulunan bu katsayının istatiksel olarak hem anlamlı hem de negatif olması hata düzeltme mekanizmasının uzun dönemde denge değerine yaklaşacak şekilde işlediğini göstermektedir. Bu sonuca göre, hata düzeltme mekanizması dengeden sapmaları \% 87 azaltacaktır. Bu sonuç Korkmaz ve Çevik (2009) tarafından yapılan ve 2004-2009 yıllarını kapsayan çalışmalarında elde ettikleri bulgular ile de örtüşmektedir. Yazarlar, VIX endeksinin gelişmekte olan ülkelerin hisse senedi piyasaları üzerindeki etkisini araştırmışlardır. Yaptıkları analizler sonucunda bulgular, VIX endeksinin Türkiye hisse senedi piyasasını etkileyerek, hisse senedi piyasalarının volatilitesini artırdığı yönündedir.

Eğer VIX endeksi çok yüksekse, piyasa kötümser olup hisse senetlerinin değerinin düşebileceği durumu göze çarpmaktadır. Ve yine bu durum hisse senetlerinin fiyatlarının düşmesinden kaynaklanan finansal kırılganlığı artıracak etki oluşturulabilmektedir. BIST 100 endeksinin VIX endeksinden etkilenme durumu ve VIX endeksinin gelecekteki volatiliteyi öngörmede başarılı olması, VIX endeksinin uluslararası ve ulusal yatırımlarda göz ardı edilmeyeceği gerçeğini ortaya koymaktadır. 


\section{Sonuc}

Finansal piyasalar arasındaki entegrasyon ülkelerin dişa açık ekonomi politikaları ile 1980'li yıllarda başlamış ve 1990’lı yıllarda ivme kazanmıştır. Böylelikle finansal piyasaların bütünleşmesi, finansal piyasalar arasındaki etkileşimi araştıran çalışmaların artmasına sebep olmuştur. VIX endeksi, S\&P 500 endeksinin volatilitesi hakkında öncül gösterge niteliği taşımaktadır. Literatürde yer alan birçok çalışmada varılan sonuç, VIX'ın S\&P 500 endeksini öngörmede başarılı olduğudur. Ancak VIX'ın etkilediği piyasalar üzerine çok az çalışma yapıldığ görülmektedir. Bu çalışmanın amacı 02/01/2009 ile 11/01/2013 dönemi içinde BIST 100 endeksi ile VIX endeksi arasındaki nedenselliği tespit etmektir. Bu kapsamda öncelikle çalışmada kullanılan zaman serilerinin durağanlıkları ADF ve PP birim kök testleri ile araştırılmış, ardından değişkenler arasında uzun dönemli ilişkinin varlığını tespit etmek için Johansen-Juselius eşbütünleşme testi yapılmıştır. Daha sonra VEC modeli sonuçlarına yer verilmiştir.

Uygulamada yer alan Johansen-Juselius eş-bütünleşme testinin sonuçları, BIST 100 endeksi ile VIX endeksi arasında uzun dönemli ilişki olduğuna işaret etmektedir. Eşbütünleşme testinin ardından uygulanan VEC modeli tahmin bulguları ise, değişkenler arasındaki uzun dönemli ilişkinin varlığını doğrulamıştır. Hata düzeltme katsayısının negatif ve anlamlı olması, uzun dönemde dengeye dönüleceğinin işaretidir ve de kısa dönem dengesizliğinin yaklaşık \% 87 gibi yüksek bir oranı da bir dönem içerisinde giderilmektedir. $\mathrm{Bu}$ sonuçlar BIST 100 endeksinin VIX endeksinin etkisinde olduğunu ifade etmektedir.

Küreselleşen dünyada, ülkelerin sermaye piyasaları arasındaki farklar makroekonomik politikalar, uzmanlaşma, bankacılık politikaları, politik istikrar veya istikrarsızlık gibi sebeplerden kaynaklanabilmektedir. Ülkelerin sermaye piyasası ilişkileri ise fon tahsisi ve riski azaltma avantajı sunmaktadır. Piyasalar arasındaki ticari ilişkiler arttıkça da, piyasaların birbirleri ile olan entegrasyonu artabilmektedir. Dğier taraftan, VIX endeksi, piyasalardaki korkuyu yansıtmaktadır. Dolayısıyla bu endeks finansal kırılganlık açısından önem taşımakta ve VIX endeksi krizlerin öncüsü olarak görülmektedir. VIX endeksindeki değişim, örneğin yüksek oranda artış, yatırımcılar açısından ihtiyatlı olmayı gerektiren durumdur. Sonuç olarak yatırımcıların, zımni volatiliteyi takip ederek, kârlı yatırım stratejilerini belirleme konusunda fikir edinebilecekleri bu çalışmadan elde edilen bir çıkarımdır. Çalışmada elde edilen bulgular, hisse senedi piyasalarına yatırım yapacak yatırımcılara ve bu alana yönelik çalışma yapacak olan araştırmacılara yol gösterici nitelik taşımaktadır.

\section{Kaynaklar}

Amira, K., Taamouti, A. ve Tsafack, G. (2011), "What Drives International Equity Correlations? Volatility or Market Direction?" Journal of International Money and Finance, 30, 1234-1263.

Ayuso, J. ve Blanco, R. (2001), "Has Financial Market Integration Increased during The Nineties" Journal of International Financial Markets, Institutions and Money, 11, 265-287.

Bali, T. G. ve Weinbaum, D. (2007), "A Conditional Extreme Value Volatility Estimator Based on -Frequency Returns" Journal of Econometrics, 105, 5-26.

Becker, R., Clements, A. E. ve McClelland, A. (2009), "The Jump Component of S\&P 500 Volatility and the VIX Index" Journal of Banking \& Finance, 33, 1033-1038.
Blair, B. J., Poon, S. H. ve Taylor, S. J. (2001), "Forecasting S\&P 100 Volatility: The Incremental Information Content of Implied Volatilities and High Frequency Index Returns" Journal of Econometrics, 105, 5-26.

Claessens, S. ve Schmukler, S. L. (2007), "International Financial Integration through Equity Markets: Which Firms from which Countries Go Global?" Journal of International Money and Finance, 26, 788-813.

Durkaya, M. ve Ceylan, S. (2006), "Vergi Gelirleri ve Ekonomik Büyüme" Maliye Dergisi, 150, 79-89.

Fleming, J. (1998), “The Quality of Market Volatility Forecasts Implied by S\&P 100 Index Option Prices" Journal of Empirical Finance, 5: 317-345.

Gujarati, D. N. (1995), Basic Econometrics. İstanbul: Literatür Yayıncılık. 838 s., İstanbul.

Hassan, M. K. ve Naka, A. (1996), "Short-run and Long-run Dynamic Linkages among International Stock Markets" International Review of Economics and Finance, 5, 387-405.

Hassan, M. K., Maroney, N. C., El-Sady, H. M. ve Telfah, A. (2003), "Country Risk and Stock Market Volatility, Predictability, and Diversification in The Middle East and Africa" Economic Systems, 27, 63-82.

Horvath, R. ve Petrovski, D. (2013), "International Stock Market Integration: Central and South Eastern Europe Compared" Economic Systems, 415, 1-11.

Konstantinidi, E., Skiadopoulos, G. ve Tzagkaraki, E. (2008), "Can The Evolution of Implied Volatility Be Forecasted? Evidence from European and US Implied Volatility Indices" Journal of Banking \& Finance, 32, 2401-2411.

Korkmaz, T. ve Çevik, E. İ. (2009), “Zımni Volatilite Endeksinden Gelişmekte Olan Piyasalara Yönelik Volatilite Yayılma Etkisi” BDDK Bankactlı ve Finansal Piyasalar, 3, 87105.

Menezes, R., Dionísio, A. ve Hassanic, H. (2012), "On The Globalization of Stock Markets: An Application of Vector Error Correction Model, Mutual Information and Singular Spectrum Analysis to The G7 countries" The Quarterly Review of Economics and Finance, 52, 369-384.

Mukherjee, K. N. ve Kumar, M. R. (2010), "Stock Market Integration and Volatility Spillover: India and Its Major Asian Counterparts" Research in International Business and Finance, 24, 235-251.

Naranjo, A. ve Protopapadakis, A. (1997), "Financial Market Integration Tests: An Investigation Using USA Equity Market" Journal of International Financial Markets, Institutions and Money, 7, 93-135

Özdemir, Z. A., Olgun, H. ve Saraçoglu, B. (2009), "Dynamic Linkages between The Center and Periphery in International Stock Markets" Research in International Business and Finance, 23, 4653.

Su, C.W. (2011), "Non-linear Causality between The Stock and Real Estate Markets of Western European Countries: Evidence from Rank Tests" Economic Modelling, 28, 845-851.

Toyoshima, Y. ve Hamori, S. (2013), "Asymmetric Dynamics in Stock Market Correlations: Evidence from Japan and Singapore" Journal of Asian Economics, 24, 117-123.

Uysal, A., Özer H. ve Mucuk, M. (2009), "Dış Borçlanma ve Ekonomik Büyüme İlişkisi: (1965-2007)" Atatürk Üniversitesi İktisadi ve İdari Bilimler Dergisi, 23, 161-177. 
Vuran, B. (2010), “İMKB 100 Endeksinin Uluslararas1 Hisse Senedi Endeksleri ile İlişkisinin Eşbütünleşim Analizi ile Belirlenmesi" İstanbul Üniversitesi İşletme Fakültesi Dergisi, 39 (1), 154-168.

Wang, J. (2007), "Foreign Equity Trading and Emerging Market Volatility Evidence from Indonesia and Thailand" Journal of Development Economics, 84, 798-811.

Yapraklı, S. (2007), “Ticari ve Finansal Dışa Açıklık ile Ekonomik Büyüme Arasındaki İlişki: Türkiye Üzerine Bir Uygulama" İstanbul Üniversitesi İktisat Fakültesi Ekonometri ve Istatistik Dergisi, 5, 67-89.

Zhou, X., Zhang, W. ve Jie, Z. (2012), "Volatility Spillovers between The Chinese and World Equity Markets" Pacific-Basin Finance Journal, 20, 247-270. 